http://jmscr.igmpublication.org/home/ ISSN (e)-2347-176x ISSN (p) 2455-0450

crossref DOI: https://dx.doi.org/10.18535/jmscr/v8i2.85

Journal Of Medical Science And Clinical Research

\title{
Efficiency of ultrasonography in detecting nonpalpable testes in children Bangladesh
}

\section{Authors \\ Dr Md. Mahabur Rahman Sarker ${ }^{1}$, Dr Md. Abdul Aziz ${ }^{2}$, Dr A. R. Khan ${ }^{3}$, Dr Mohammad Golam Mostafa ${ }^{4}$}

${ }^{1}$ Assistant Professor, Department of Pediatric Surgery, Shaheed Ziaur Rahman Medical College, Bogura, Bangladesh.

${ }^{2}$ Professor, Department of Pediatric Surgery, Bangladesh Institute of Child Health, Dhaka Shisu (Children) Hospital, Dhaka, Bangladesh

${ }^{3}$ Professor, Department of Pediatric Surgery, Bangladesh Institute of Child Health, Dhaka Shisu (Children) Hospital, Dhaka, Bangladesh

${ }^{4}$ Professor and Head, Department of Histopathology, National Institute of Cancer Research and Hospital, Mohakhali, Dhaka, Bangladesh

*Corresponding Author

\section{Dr Md. Mahabur Rahman Sarker}

\begin{abstract}
Objectives: In this study our main goal is to evaluate the efficiency of ultrasonography in detecting nonpalpable testes in children Bangladesh.

Methods: This cross-sectional observational study was done in the department Pediatric Surgery, Dhaka Shisu (children) Hospital (DSH), Dhaka, from March 2014 to September 2015.The study included 30 children with nonpalpable testis either unilateral or bilateral. In each case, information about the patient was collected in a prescribed questionnaire after getting written consent from the parents or legal guardians in a preformed consent form.
\end{abstract}

Results: During the study left sided impalpable testis was predominant as $36 \%$, then the right side $17 \%$ and bilateral problem around 47\%.one intra abdominal testis also found atrophic rendered as absent and excised. ultrasonogram could visualize 21 (48\%) testes, of them inguinal canal 19 (43.5\%), and abdominal $02(4.5 \%)$.

Conclusion: from our study we can conclude that, ultrasonogram can be used in terms of diagnosis of nonpalpable undescended testis in children. Moreover, therapy can be outlined and offered at the same time during surgical procedure.

Keywords: Intra abdominal testis, nonpalpable testes, laparoscopy surgery.

\section{Introduction}

Undescended testis, also known as cryptorchidism, is defined as a condition in which testis cannot be made to reach the bottom of the scrotum. ${ }^{1}$
Failure of testicular descent is one of the most common genitourinary disorder in young boys, being seen in $0.8-2 \%$ of full-term boys and 18$30 \%$ of premature boys. Approximately $20 \%$ of undescended testis (UDT) is nonpalpable on 
physical examination. ${ }^{2}$ There are four possible explanations for this phenomenon. First, the testis may be situated in the scrotum or inguinal canal, but is too small or there is too much subcutaneous adipose tissue. Second, the testis is located inside a patent processus vaginalis in the inguinal canal and may be intermittently inguinal and abdominal in position. Localization of impalpable testis is a significant problem in pediatric patients. Many diagnostic methods such as Ultrasonography, CT scan, MRI and Laparoscopy have been used to locate non palpable testis.

Inguino-abdominal ultrasonography is recommended as the first step after clinical examination as it avoids ionizing radiation, cost effective, having shorter scanning time \& the fact that it does not require sedation or oral contrast. It is the initial method in evaluation of non palpable testis. $^{3-4}$

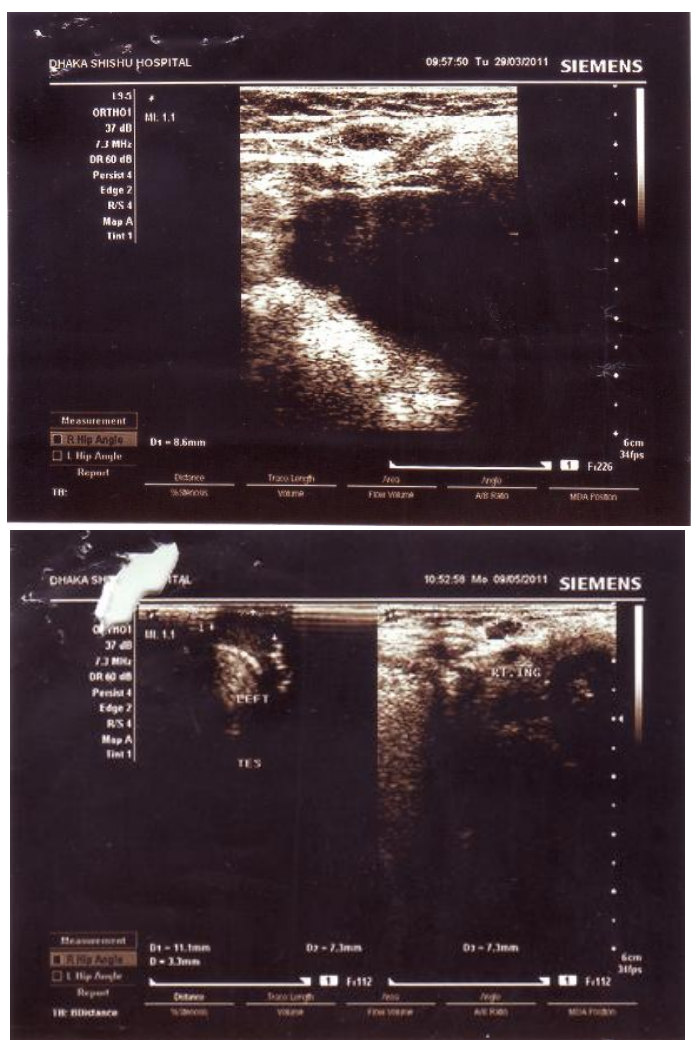

Figure1a and 1b: shows right sided canalicular testis and left sided canalicular testis

In this study our main goal is to evaluate the efficiency of ultrasonography in detecting nonpalpable testes in children Bangladesh.
Objective

General Objective

- To assess the efficiency of ultrasonography in detecting nonpalpable testes in children Bangladesh.

\section{Specific Objectives}

- To identify affected side of the patients.

- To detect location of testes.

\begin{tabular}{|c|c|}
\hline \multicolumn{2}{|l|}{ Methodology } \\
\hline Type of study & $\begin{array}{l}\text { Cross-sectional observational } \\
\text { study }\end{array}$ \\
\hline Place of study & $\begin{array}{l}\text { Department of Pediatric Surgery, } \\
\text { Dhaka Shisu (children) Hospital } \\
\text { (DSH), Dhaka. }\end{array}$ \\
\hline Study period & March 2014 to September 2015. \\
\hline $\begin{array}{l}\text { Study } \\
\text { population }\end{array}$ & $\begin{array}{l}\text { The study included } 30 \text { children } \\
\text { with nonpalpable testis either } \\
\text { unilateral or bilateral. }\end{array}$ \\
\hline $\begin{array}{l}\text { Sampling } \\
\text { technique }\end{array}$ & Purposive \\
\hline
\end{tabular}

\section{Inclusion Criteria}

- Patients with non-palpable testes under the age of 16 years.

\section{Method}

During the study, the principal investigator had collected the data and evaluated the relevant investigations in the department of pediatric Surgery, Dhaka Shisu (children) Hospital. A Data sheet was filled out during data collection. In each case, information about the patient was collected in a prescribed questionnaire after getting written consent from the parents or legal guardians in a preformed consent form.

\section{Data Analysis}

Statistical analysis was performed using the Statistical package for social science SPSS version 15.0. A descriptive analysis was performed for clinical features and results were presented as mean \pm standard deviation for quantitative variables and numbers (percentages) for qualitative variables. Fisher's exact test was 
used for categorical variables. All p-values were considered as statistically significant if $<0.05$.

\section{Results}

In figure- 2 shows age distributions of the patients where most of the patients were belong to 2-5 years age group. The following figure is given below in detail:

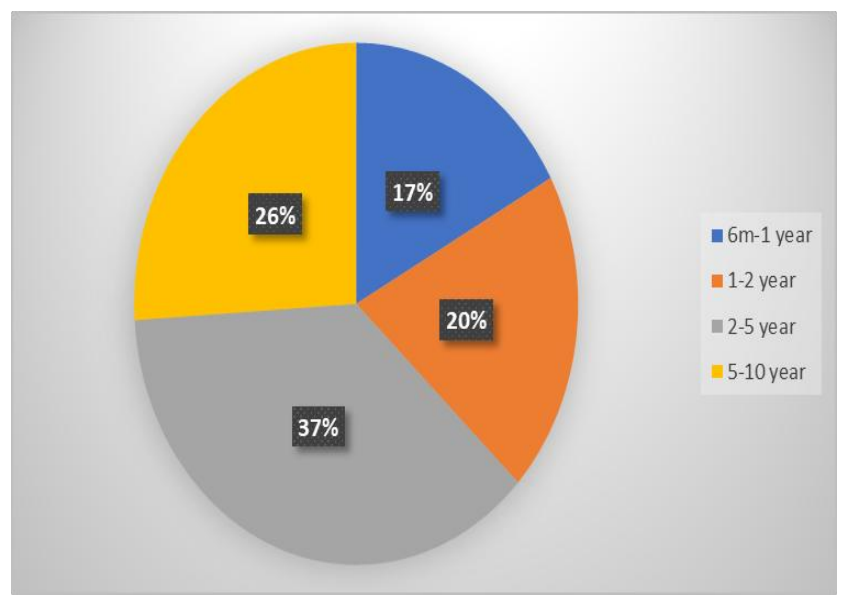

Figure-2: Age distributions of the patients

In figure-3 shows distribution of the patients according to side effected where left sided impalpable testis was predominant as $36 \%$, then the right side $17 \%$ and bilateral problem around $47 \%$. The following figure is given below in detail:

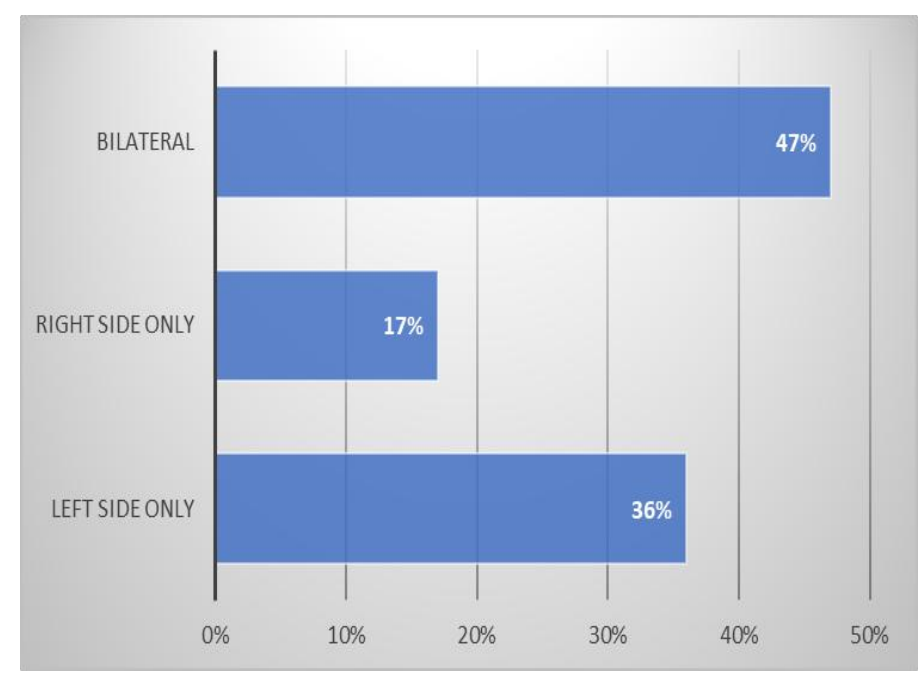

Figure-3: Distribution of the patients according to side effected

In table-1 shows ultrasonographic location of testes where ultrasonogram could visualize 21 (48\%) testes, of them inguinal canal 19 (43.5\%), and abdominal $02(4.5 \%)$. The following table is given below in detail:
Table-1: Ultrasonographic location of testes (30 patients with 44 NPT).

\begin{tabular}{|l|c|c|}
\hline Location & Frequency & Percentage (\%) \\
\hline Inguinal canal & 19 & $43.5 \%$ \\
\hline Intra- abdominal & 02 & $4.5 \%$ \\
\hline Not visualized & 23 & $52 \%$ \\
\hline Total & 44 & $100 \%$ \\
\hline
\end{tabular}

In table-2 shows diagnostic efficacy of Ultrsonogram in relation to visualizing testis where one intra abdominal testis also found atrophic rendered as absent and excised. The following table is given below in detail:

Table-2: Diagnostic efficacy of Ultrsonogram in relation to visualizing testis

\begin{tabular}{|l|c|c|c|}
\hline & \multicolumn{2}{|c|}{ Laparoscopy } & \\
\hline USG findings & Present & Absent & Total \\
\hline Visualize & 20 & 01 & 21 \\
\hline Not visualize & 20 & 03 & 23 \\
\hline Total & 40 & 04 & 44 \\
\hline
\end{tabular}

Sensitivity: $50 \%$

Specificity: $75 \%$

Positive predictive value: $95 \%$

Negative predictive value: $13 \%$

Accuracy: $52 \%$

\section{Discussion}

Over the years, a wide range of investigation from vascular and imaging technique to laparoscopy have been used in detecting NPT. Ultrasound is a non-invasive diagnostic method, which is applied in almost all clinics. The effectiveness of USG examination always depends on the experience of the radiologist and the technical equipment as well as on the patients' individual tissue constitution. The difficulties of these technique result from physical limitations of sonography, such as negative correlation between resolution and penetration that makes USG imaging difficult in deeper regions. It is especially preferred for its high accuracy in the diagnosis of superficially located inguinal testes.

One study calculated the diagnostic effectiveness of sonography as $95 \%$ for inguinal testes, $33 \%$ for atrophic inguinal testes and $9 \%$ for abdominal testes. ${ }^{5}$ In present study, 30 patients with 44 nonpalpable testes cases, USG detect 21(48\%) 
testes and fail to detect $23(52 \%)$ testes where sensitivity was found $50 \%$. In current series USG did not provide extra benefits compared to physical examination in non palpable testes cases. There is also no consensus about the efficiency of US in the literature in children cases.

In our series we had done only USG for all the patients and two cases detection of impalpable testis were evident as intra-abdominal testis where laparoscopy was necessary to conclude. Although presenting a better quality, both computed tomography and nuclear magnetic resonance lack sufficient sensitivity and specificity to be considered as gold standard diagnostic tools. ${ }^{6}$

More recently, the magnetic resonance angiography was introduced with sensibility of $96 \%$ and specificity of $100 \%$, but it is still a new method, with high costs, also requiring general anesthesia in children. ${ }^{7}$

\section{Conclusion}

From our study we can conclude that, ultrasonogram can be used in terms of diagnosis of non-palpable undescended testis in children. Moreover, therapy can be outlined and offered at the same time during surgical procedure.

\section{References}

1. Cain M, Garra B, Gibbon MD. 1996, ' Serotal- inguinal ultrasonography: A technique for identifying the non palpable testis without laparoscopy', The Journal of Urology vol. 170, pp.791-794.

2. Cisek LJ, Peters CA, Atala A, Bauer SB, Diamond DA, Retik AB.1998, Current findings in diagnostic laparoscopic evaluation of the nonpalpable testis. $J$ Urol. Vol.160:1145-50.

3. Colodny AH. 1986, Undescended testesis surgery necessary? [Editorial]. $N$ Engl J Med. Vol.314:510-1.
4. Cortes D, Thorup JM, Lenz K, Beck BL, Nielsen OH. 1995, 'Laparoscopy in 100 consecutive patients with 128 impalpable testes', Br J Urol., Vol. 75, pp 281-7.

5. Cortesi N, Ferrari P, Zambarda E, Manenti A, Baldini A, Morano FP.1976, Diagnosis of bilateral abdominal cryptorchidism by laparoscopy. Endoscopy. Vol.8:pp33-4.

6. Docimo SG.1996, Testicular descent and ascent in the first year of life. Urolog vol.48:pp458-60

7. Docimo SG, Peters CA. 2005, 'Pediatric endourology and laparoscopy', In Campbell's Urology, Walsh, PC, Retik, AB, Vaughan, ED, Wein, AJ, Saunders Company, Philadelphia, 8th Ed., pp 23532394. 